\title{
Economic Organization, Distribution and the Equality Issue: The Marx-Engels Perspective
}

SAMUEL HOLLANDER

sholland@bgumail.bgu.ac.il

Department of Economics, Ben-Gurion University of the Negev, Beer Sheva, Israel 84105

\begin{abstract}
This paper has four related themes. It demonstrates that Marx's Communism in its first or Socialist phase would recognize the essential inequality of labour on grounds of efficiency and growth. It offers an explanation for the apparent paradox that Marx and Engels championed a fully-fledged control system notwithstanding appreciation of the allocation functions of a competitive market system. It highlights common ground relating to market process between Marx and Engels and the modern "classical liberals" Mises and Hayek. And it traces the evolutionary nature of the Marx-Engels perspective on transitions between and within economic systems.
\end{abstract}

Key Words: socialist systems, comparative systems, transitional economics, Marxian socialism, classical liberalism

JEL classification: B14, B24, B31, B51, B53, P30

\section{Introduction}

My first concern is the treatment of distribution by Marx and Engels within the general framework of "Historical Materialism." After a brief review of their rejection of egalitarian schemes based on "justice" or "morality" (Section 2.1), I proceed to their objections on grounds of the impossibility of divorcing distribution from conditions of production and the related exchange system. I demonstrate first that growing inequality is accorded a strategic and essential role in the evolution of a capitalist-exchange economy (Section 2.2). (In any event, Marx and Engels seem to have downplayed the quantitative significance for labour even of major transfers.) That the pattern of distribution could not be altered unilaterally without damaging consequences for production, is then shown to govern their hostility to schemes of Communist organization entailing wages paid according to "equal right" and "the undiminished proceeds of labour" (Section 2.3). In brief, Marx's Communism in its first phase (sometimes referred to as the Socialist phase), when there remains a residual influence exerted by the preceding institution, ${ }^{1}$ would recognize the essential inequality of labour on grounds of efficiency and growth; the celebrated dictum "from each according to his abilities to each according to his needs" applied only in a utopian phase. Engels' rendition of these themes is approached in terms of his critique of Dühring (Section 3).

A high degree of respect for the allocative role of markets is then brought into the picture to explain Marx's rejection of contemporary rent-confiscation and price-control schemes (Section 4). I seek in this context to understand the championship of a 
fully-fledged Control system-social ownership of the means of production, central planning, abolition of markets for labour and goods, consumer rationing — notwithstanding such respect, and notwithstanding Engels' severe condemnation of Rodbertus and Dühring for neglecting the role of competition in their socialist schemes. Essentially, the system would ideally be simplified to the point that a sophisticated allocation mechanism was not required.

In Section 5, I draw some unexpected parallels entailing common ground on the approach to distribution and market process between Marx and Engels and the modern "conservative" or "classical liberal" writers Mises and Hayek. An Appendix touches on aspects of Mises' reading of Marx on these and related matters.

An overview (Section 6) focuses on the cautious evolutionary nature of the Marx-Engels perspective: the development within Capitalism of forces preparing the ground for a political take-over by the proletariat, preeminently nationalization of industry; the period of transition to full Communism with continued though diminishing reliance on a capitalist sector, to which period the Communist Manifesto applied; and the two phases of Communism the first of which entailing a measure of inequality reflected in differential wage rates.

\section{Objections to Egalitarian Reform}

\subsection{The Rejection of Claims Based on Justice}

Marx insisted that his case for socialism did not turn on the immorality or inequity of capitalist wage-setting in particular or the pattern of distribution in general (Baumol 2001:231). ${ }^{2}$ Rather to the contrary, "we must assume throughout that the wages being paid are economically just, i.e. determined by the general laws of political economy" (Grundrisse 1857/8; $\mathrm{MECW}^{3}$ 28:354). Or again: "is [present-day distribution] not, in fact, the only 'fair' distribution on the basis of the present-day mode of production?" (Critique of the Gotha Programme 1875; MECW 24:84). In his manuscript notes (completed after January 1881) on Adolphe Wagner's Lehrbuch der politischen oekonomie, Marx protests that he was falsely represented by Wagner as maintaining that profit was "a deduction from, or robbery of, the worker," whereas his position was the precise opposite:

On the contrary, I depict the capitalist as the necessary functionary of capitalist production and demonstrate at great length that he not only "deducts" or "robs" but enforces the production of surplus value, thus first helping to create what is to be deducted; what is more, I demonstrate in detail that even if only equivalents were exchanged in the exchange of commodities, the capitalist-as soon as he pays the worker the real value of his labour-power-would have every right, i.e. such right as corresponds to this mode of production, to surplus-value (MECW 24:535).

The obscure man falsely attributes to me the view that "the surplus-value produced by the workers alone remains, in an unwarranted manner, in the hands of the capitalist entrepreneurs." ... In fact I say the exact opposite: that the production of commodities must necessarily become "capitalist" production of commodities at a certain point, and 
that according to the law of value governing it, the "surplus-value" rightfully belongs to the capitalist and not the worker (p. 558).

And in Capital itself, Marx referred to "a very cheap sort of sentimentally which declares [the] method of determining the value of labour-power, a method prescribed by the very nature of the case, to be a brutal method" (MECW 35:183).

Engels read Marx to this same effect in his Preface to the first German edition of Poverty of Philosophy (1885):

According to the laws of bourgeois economics, the greatest part of the product does not belong to the workers who have produced it. If we now say: that is unjust, that ought not to be so, then that has nothing immediately to do with economics. We are merely saying that this economic fact is in contradiction to our sense of morality. Marx, therefore, never based his communist demands upon this, but upon the inevitable collapse of the capitalist mode of production which is daily taking place before our eyes to an ever growing degree; he says only that surplus value consists of unpaid labour, which is a simple fact (MECW 26:281-282).

We may add that in his contribution to The Labour Standard "A Fair Day's Wages for a Fair Day's Work" (7 May 1881), Engels defined the very concept "a fair day's wages," as the subsistence wage, namely "under normal conditions... the sum required to procure to the labourer the means of existence necessary, according to the standard of life of his station and country, to keep himself in working order and to propagate his race" (MECW 24:376-377).

\subsection{The Economic Role of Inequality}

I turn now to a strictly economic objection to egalitarian reform. Marx in his Poverty of Philosophy (1847) objected to Proudhon's egalitarianism partly on grounds of a technical error involving confusion of labour embodied with labour commanded: "Let us see to what extent the application of labour time as a measure of value is incompatible with existing class antagonism and the unequal distribution of the product between the individual worker and the owner of accumulated labour", i.e., to what extent "exchange of products measured by labour time results in an equality of payment for all the producers"-as Proudhon maintained (MECW 6:125-126).

Proudhon had in fact proven nothing: "All the 'equalitarian' consequences which M. Proudhon deduces from Ricardo's doctrine are based on a fundamental error. He confounds the value of commodities measured by the quantity of labour embodied in them with the value of commodities measured by "the value of labour" (p. 127). The identification in question implied that labour was the sole factor - an error compounded by the further notion that labour was of uniform quality (p. 129) — and could be seen in the invalid identification of production costs with wage costs: "M. Proudhon makes the value of labour the 'determining cause' of the value of products to such an extent that for him wages, the official name for the 'value of labour,' form the integral price of all things" (p. 129). 
Beyond this there is the principle of Historical Materialism - that "the mode of production" corresponding to each particular form of class antagonism governed the mode of exchange (including products and factors) rather than the reverse. Consider from this perspective the economic role of income inequality insisted on in reaction to Proudhon's observation in 1846 that "with the progress of collective industry, every day's individual labour produces a greater and greater product, and whereas therefore by a necessary consequence, the worker with the same wage ought to become richer every day, there actually exist estates in society which profit and others which decay" (cited 158). Proudhon's question "why was not the English worker of 1840 twenty-seven times as rich as the one of 1770"- - assuming a corresponding productivity increase-implied a failure to appreciate the positive necessity in a class-organized private-property society of "classes which profited and classes which decayed"- the economic role of income inequality — such decay or "dépérissement" being a condition for "the development of productive forces" and the corresponding "surplus left by labour":

In raising such a question one would naturally be supposing that the English could have produced this wealth without the historical conditions in which it was produced, such as: private accumulation of capital, modern division of labour, automatic workshops, anarchical competition, the wage system - in short, everything that is based upon class antagonism. Now, these were precisely the necessary conditions of existence for the development of productive forces and of the surplus left by labour. Therefore, to obtain this development of productive forces and this surplus left by labour there had to be classes which profited and classes which decayed (p. 159). ${ }^{5}$

Moreover, Proudhon's model, designed to explain the source of surplus in terms of a "person society", missed the point entirely. The true "Prometheus" was class based; and any program of redistribution in the class-based society implied the undermining of productive capacity and the ability to produce a surplus:

What then, ultimately, is this Prometheus resuscitated by M. Proudhon? It is society, social relations based on class antagonism. These relations are not relations between individual and individual but between worker and capitalist, between farmer and landlord, etc. Wipe out these relations and you annihilate all society, and your Prometheus is nothing but a ghost without arms or legs; that is, without automatic workshops, without division of labour - in a word, without everything that you gave him to start with in order to make him obtain this surplus left by labour.

Of this consequence, Proudhon seemed unaware: "If then, in theory, it sufficed to interpret, as M. Proudhon does, the formula of the surplus left by labour in the equalitarian sense, without taking into account the actual conditions of production, it should suffice, in practice, to share out equally among the workers all the wealth at present acquired, without changing in any way the present conditions of production"- - which was inconceivable. ${ }^{6}$ In any event, Marx here added the estimate that "[s]uch a distribution would certainly not assure a high degree of comfort to the individual participants" (see also, p. 15). 


\subsection{The Case for Inequality Under Communism ${ }^{7}$}

Marx's general methodological objection to the Party programme of 1875 is that to focus on distribution at all was to put the cart before the horse, since the distributional pattern in any system is a necessary outcome of "the mode of production":

Quite apart from the analysis so far given, it was in general a mistake to make a fuss about so called distribution and put the principle stress on it.

Any distribution whatever of the means of consumption is only a consequence of the distribution of the conditions of production themselves. The latter distribution, however, is a feature of the mode of production itself. The capitalist mode of production, for example, rests on the fact that the material conditions of production are in the hands of non-workers in the form of capital and land ownership, while the masses are only owners of the personal condition of production, of labour power. If the elements of production are so distributed, then the present-day distribution of the means of consumption results automatically. If the material conditions of production are the collective property of the workers themselves, then there likewise results a distribution of the means of consumption different from the present one. The vulgar socialists (and from them in turn a section of the Democrats) have taken over from the bourgeois economists the consideration and treatment of distribution as independent of the mode of production and hence the presentation of socialism as turning principally on distribution. After the real relation has long been made clear, why retrogress again? (Critique of the Gotha Programme; MECW 24:87-88).

Marx's more specific concern was the Party's failure to recognize that the principle applied to any system-including a Communist system, with particular reference to the

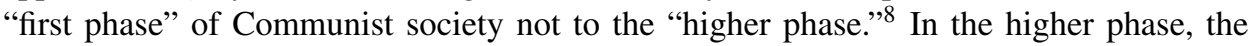
distributive rule "from each according to his abilities to each according to his needs" would apply, the division of labour would be abolished, and in general the scarcity problem would be greatly diminished, though apparently not obliterated:

In a higher phase of communist society, after the enslaving subordination of the individual to the division of labour, and thereby also the antithesis between mental and physical labour, has vanished; after labour has become not only a means of life but life's prime want; after the productive forces have also increased with the all-round development of the individual, and all the springs of common wealth flow more abundantly-only then can the narrow horizon of bourgeois right be crossed in its entirety and society inscribe on its banners: From each according to his abilities, to each according to his needs! (p. 87).

Now the Programme itself is described by Marx as "altogether deplorable as well as demoralising for the party" (letter to Wilhelm Bracke, May 5 1875; MECW 24:78). And in the Critique itself he actually refers to the Programme's references to distribution based on the "undiminished proceeds of labour" and on "equal right" and "fair distribution" as a crime: 
I have dealt at greater length with the "undiminished proceeds of labour," on the one hand, and with "equal right" and "fair distribution," on the other, in order to show what a crime it is to attempt, on the one hand, to force on our Party again, as dogmas, ideas which in a certain period had some meaning but have now become obsolete verbal rubbish, while again perverting, on the other, the realistic outlook, which it cost so much effort to instill into the Party but which has now taken root in it, by means of ideological, legal and other trash so common among the Democrats and French Socialists (MECW 24:87).

Consider then Marx's response to Item One of the Programme: "Labour is the source of all wealth and all culture, and since useful labour is possible only in society and through society, the proceeds of labour belong undiminished with equal right to all members of society" (p. 81). Marx rejected the initial declaration: "Nature is just as much the source of use values (and it is surely of such that material wealth consists!) as labour, which itself is only the manifestation of a force of nature, human labour power." As for "an undiminished distribution," there is first the general objection that "[i]f useful labour is possible only in society and through society, the proceeds of labour belong to society-and only so much therefrom accrues to the individual worker as is not required to maintain the 'condition' of labour, society" (p. 82). Marx adds that "the whole paragraph, bungled in style and content, is only there in order to inscribe the Lassallean catchword of the "undiminished proceeds of labour' as a slogan at the top of the party banner" (p. 83). He promises to "return later to the 'proceeds of labour,' 'equal right,' etc., since the same thing recurs in a somewhat different form further on", alluding to the third item of the programme: "The emancipation of labour demands the raising of the means of labour to the common property of society and the collective regulation of the total labour with a fair distribution of the proceeds of labour."

Now it is specifically to the so-called "fair distribution" that Marx objects, not to "collective regulation..." which implies central planning of activity. Before proceeding to his objections to the programme we should confirm the support for central control since it is alluded to only in scattered remarks rather than systematically and cannot simply be taken for granted in what follows.

Brief mention is made of "co-operative societies" in the Gotha Programme (pp. 93-94), but with no suggestion that Marx favoured them as a feature of Communist society. Central planning is apparently alluded to in The German Ideology (1845-1846) - a joint product of Marx and Engels: “... with the abolition of... private property, with the communist regulation of production... the power of the relation of supply and demand is dissolved into nothing, and men once more gain control of exchange, production..." (MECW 5:48). In The Communist Manifesto Marx affirms that the outcome of the proposed transitional programme would be that "all production [is] concentrated in the hands of a vast association of the whole nation" (MECW 6:698-699). This is the formulation in the 1888 English edition, namely Samuel Moore's translation edited by Engels. The German editions, however, have "in the hands of associated individuals," which may suggest some form of cooperative organization. But central planning seems to be the favoured solution, for we also read in the Manifesto of the centralisation of "all instruments of production in the hands of the State" 
(p. 504). In Capital II, Marx refers to "collective" as distinct from capitalist production implying central organization (MECW 36:149, 450); and he points out that with the elimination of "money capital"-including preeminently credit-" [s]ociety distributes labour power and means of production to the different branches of production" (p. 356; emphasis added). Capital III points to the situation "where production is under the actual, predetermining control of society," such control "establish[ing] a relation between the volume of social labour time applied in producing definite articles, and the volume of the social want to be satisfied by these articles" (MECW 37:186). There is also reference to "socialised man, the associated producers, rationally regulating their interchange with Nature, bringing it under their common control..." (p. 807). Even when explicit allowance is made for cooperation it is not J.S. Mill's competing cooperatives that Marx had in mind, but some form of cooperation under central control:

If co-operative production is not to remain a sham and a snare; if it is to supersede the Capitalist system; if united co-operative societies are to regulate national production upon a common plan, thus taking it under their own control, and putting an end to the constant anarchy and periodic convulsions which are the fatality of Capitalist production — what else, gentlement, would it be but Communism... (The Civil War in France (1871), MECW 22:335; emphasis added). ${ }^{9}$

With this frame of reference regarding desirable organization in mind, we turn to Marx's specific objection to the distribution of an "undiminished product" proposed in the Party programme of 1875. Marx insists first on the deductions that would have to be made from the social product on purely economic grounds-deductions for capital maintenance, net investment and insurance before distribution for consumption purposes could be allowed:

But "all members of society" and "equal right" are obviously mere phrases. The crucial point is this, that in this communist society every worker must receive his "undiminished" Lassallean "proceeds of labour."

Let us take first of all the words "proceeds of labour" in the sense of the product of labour; then the collective proceeds of labour are the total social product. From this must now be deducted: First, cover for replacement of the means of production used up. Secondly, additional portion for expansion of production. Thirdly, reserve or insurance funds to provide against accidents, disturbances caused by natural factors, etc.

These deductions from the "undiminished proceeds of labour" are an economic necessity and their magnitude is to be determined according to available means and forces, and party by computation of probabilities, but they are in no way calculable by equity (MECW 24:84).

In essence, labour must be subject to the same "deductions" to meet gross and net investment requirements as under Capitalism. The objections to Proudhon (see, p. 8) would thus not apply. And that is not all, for after the investment-related deductions there were further deductions: 
First, the general costs of administration not directly appertaining to production. This part will, from the outset, be very considerably restricted in comparison with presentday society and it diminishes in proportion as the new society develops.

Secondly, that which is intended for the common satisfaction of needs, such as schools, health services, etc. From the outset this part grows considerably in comparison with present-day society and it grows in proportion as the new society develops.

Thirdly, funds for those unable to work, etc., in short for what is included under so-called official poor relief today (p. 85).

We come now to the matter of "fair" in the sense of "equal" distribution. It is readily allowed that "what the producer is deprived of in his capacity as a private individual benefits him directly or indirectly in his capacity as a member of society." Nevertheless, Marx presumes that the "equal" distribution- "which the Programme, under Lassallean influence, has alone in view in its narrow fashion"-applies specifically "to that part of the means of consumption which is divided among the individual members of the collective," or to distribution for private ends. What follows points to Marx's adherence to a system involving labour-certificates and the absence of markets:

The social working day consists of the sum of the individual hours of work; the individual labour time of the individual producer is the part of the social working day contributed by him, his share in it. He receives a certificate from society that he has furnished such and such an amount of labour (after deducting his labour for the common funds), and with this certificate he draws from the social stock of means of consumption as much as the same amount of labour costs. The same amount of labour which he has given to society in one form he receives back in another (p. 86). ${ }^{10}$

But Marx goes a step further. What matters is application of an "equal standard," not the crude equality envisaged by the Party, and such application implies recognition of the essential inequality of labour:

But one man is superior to another physically or mentally and so supplies more labour in the same time, or can work for a longer time; and labour, to serve as a measure, must be defined by its duration or intensity, otherwise it ceases to be a standard of measurement. This equal right is an unequal right for unequal labour. It recognises no class distinctions, because everyone is only a worker like everyone else; but it tacitly recognises the unequal individual endowment and thus productive capacity of the workers as natural privileges. It is, therefore a right of inequality, in its content, like every right. Right by its nature can exist only as the application of an equal standard; but unequal individuals (and they would not be different individuals if they were not unequal) are measurable by an equal standard only insofar as they are made subject to an equal criterion, are taken from a certain side only, for instance, in the present case, are regarded only as workers and nothing more is seen in them, everything else being ignored (pp. 86-87). ${ }^{11}$ 
The concern here is entirely with natural differences between individuals with regard to "talent" - physical and mental. Nothing is said either of productivity differentials relating to learned skills, or of the sort of consideration that Adam Smith and J.S. Mill take into account in their wage-structure analyses, namely the characteristics attached to various jobs and the attitudes towards them. The contrast is striking. For Smith and Mill the non-pecuniary characteristics explain how under competitive equilibrium conditions wage differentials exist despite natural equality. But Marx assumes natural inequality and would have had no reason to appeal to such differentials in the analysis of competitive conditions and a fortiori that of collective organization.

That natural inequality of labour had to be recognized in the "first phase" is represented as an inevitable "defect" in a communist society which has just emerged "after prolonged birth pangs from capitalist society. Right can never be higher than the economic structure of society and its cultural development which this determines" (p. 87). This stage entails full-fledged common ownership and an absence of markets, a stage beyond the period of transition from capitalism discussed in the Communist Manifesto (see Section 6). Marx's point is that in the first stage of communist society the original capitalist system nonetheless leaves its mark in sharp contrast, it is throughout implied, to the ultimate stage:

Within the collective society based on common ownership of the means of production, the producers do not exchange their products; just as little does the labour employed on the products appear here as the value of these products, as a material quality possessed by them, since now, in contrast to capitalist society, individual labour no longer exists in an indirect fashion but directly as a component part of the total labour. The phrase "proceeds of labour," objectionable even today on account of its ambiguity, thus loses all meaning.

What we are dealing with here is a communist society, not as it has developed on its own foundations, but on the contrary, just as it emerges from capitalist society, which is thus in every respect, economically, morally and intellectually, still stamped with the birth-marks of the old society from whose womb it emerges. Accordingly, the individual producer receives back from society - after the deductions have been madeexactly what he gives to it. What he has given to it is his individual quantum of labour...

Here obviously the same principle prevails as that which regulates the exchange of commodities, as far as this is the exchange of equal values. Content and form are changed, because under the altered circumstances no one can give anything except his labour, and because, on the other hand, nothing can pass to the ownership of individuals except individual means of consumption. But, as far as the distribution of the latter among the individual producers is concerned, the same principle prevails as in the exchange of commodity-equivalents; a given amount of labour in one form is exchanged for an equal amount of labour in another form.

Hence, equal right here is still in principle—bourgeois right, although principle and practice are no longer at loggerheads, while the exchange of equivalents in commodity exchange only exists on the average and not in the individual case.

In spite of this advance, this equal right is still constantly encumbered by a bourgeois limitation. The right of the producers is proportional to the labour they supply; the 
equality consists in the fact that measurement is made with an equal standard, labour (pp. 85-86). ${ }^{12}$

And it is precisely at this point that Marx insists that the principle of distribution based on equal labour implies inequality. ${ }^{13}$

\section{Engels on Dühring}

The principle of Historical Materialism governs the critique by Engels of Eugen Dühring's Revolution in Science - the celebrated Anti-Dühring of $1878 .{ }^{14}$ Distribution on this principle is the dependent variable:

The materialist conception of history starts from the proposition that the production and, next to production, the exchange of things produced, is the basis of all social structure; that in every society that has appeared in history, the manner in which wealth is distributed and society divided into classes or estates is dependent upon what is produced, how it is produced, and how the products are exchanged (MECW 25:254).

More specifically, characteristic of each historical stage is growing inequality of distribution, which signals "that the community is already beginning to break up;" this applies quite generally though accompanied under capitalism by the emergence of sharp class differences (pp. 136-137). The indication provided by inequality that "the community is already beginning to break up" reflects the necessitarian role played by inequality-that inequality is inevitable and incorrigible except by means of a transformation of the mode of production and exchange. As for the capitalist stage, the process had evolved with great rapidity: "modern capitalist production, which is hardly three hundred years old and has become predominant only since the introduction of modern industry, that is, only in the last hundred years, has in this short time brought about antitheses in distribution-concentration of capital in a few hands on the one side and concentration of the propertyless masses in the big towns on the other-which must of necessity bring about its downfall" (p. 137). In this sense, distribution was "not a merely passive result of production and exchange [but] in its turn reacts upon both of them."

From all this there also emerges the irrelevance of any approach to inequality based on appeal to morality and justice; in fact social abuses- "necessary consequences" of the existing mode of production-do not even appear as an injustice to the "exploited masses" until the appropriate historical moment (pp. 137-138). Accordingly, "[t]he task of economic science"- "Scientific Socialism"-was "to show that the social abuses which have recently been developing are necessary consequences of the existing mode of production, but at the same time also indications of its approaching dissolution; and to reveal, within the already dissolving economic form of motion, the elements of the future new organisation of production and exchange which will put an end to those abuses" (p. 138).

By contrast, the "new" (eighteenth-century) science of political economy presented the laws of production and exchange as "eternal laws of nature. . . deduced from the nature of man" not as an expression of the "conditions and requirements of their epoch." Engels 
had in mind here Smith and the Physiocrats (p. 139), but Dühring too was in the same mold: he "could not offer us anything except a bad translation of Rousseau's theory of equality into the language of socialism, much as one has long been able to hear much more effectively rendered in any workers' tavern in Paris" (p. 141). Engels himself does not hesitate to speak the language of "morality"; his point is the uselessness of all such appeals until the time is ripe (p. 145). Thus calls for "the abolition of class antagonisms and class distinctions... up to 1830 had left the working and suffering classes cold." This was no longer the case; and Engels' summary explanation contains all the essentials of the Marxian position regarding the "crying contradiction" between the system of distribution based on the advanced capitalist mode of production, and that mode itself-assuring the inevitable "revolution which will put an end to all class distinctions"- an account including (as usual) reference to both the downward absolute trend in real wages and cyclical instability (pp. 145-146).

Dühring's failure manifested itself precisely in his use of "force" to understand distributive patterns, and his appeal to a mutable standard of morality and law:

Firstly, he saves himself the trouble of explaining the various forms of distribution which have hitherto existed, their differences and their causes; taken in the lump, they are simply of no account-they rest on oppression, on force. Secondly, he thereby transfers the whole theory of distribution from the sphere of economics to that of morality and law, that is, from the sphere of established material facts to that of more or less vacillating opinions and sentiments. He therefore no longer has any need to investigate or to prove things; he can go on declaiming to his heart's content and demand that the distribution of the products of labour should be regulated, not in accordance with its real causes, but in accordance with what seems ethical and just to him, Herr Dühring. But what seems just to Herr Dühring is not at all immutable, and hence very far from being a genuine truth (p. 144).

Marx we have seen estimated that the redistribution envisaged in Proudhon's scheme "would certainly not assure a high degree of comfort for the individual participants" (see, p. 8). Engels too implies as much in Anti-Dühring by minimizing both the responsibility of "force" (including state intervention) in aggravating income inequality and its potential to reduce it.

Marx, as we know, insisted on wage differentials as a necessary feature even of the first stage of Communism and a fortiori under capitalism. Now Dühring condemned Marx for adopting a typically bourgeois perspective and Engels leaped to Marx's defence, insisting on wage-scale differentials under Capitalism on the grounds that "[i]n a society of private producers, private individuals or their families pay the cost of training the qualified worker" (p. 187). Moreover, understanding Dühring as denying that differential values emerged as a result of compound labour, he pointed out how fortunate it was for Dühring "that fate did not make him a manufacturer, and thus saved him from fixing the value of his commodities on the basis of this new rule [of treating all labour equally] and thereby running infallibly into the arms of bankruptcy" (p. 185). But the complaint is extended: Dühring applied his rule to his future commune "entailing the pure heavenly air of equality and justice." By contrast, under Engels" vision of socialism, the planners would ascribe "greater values" 
to productions of compound labour, though pay differentials would not be recognized: "In a socialistically organised society, these costs [of training] are borne by society, and to it therefore belong the fruits, the greater values produced by compound labour. The worker himself has no claim to extra pay. And from this, incidentally, follows the moral that at times there is a drawback to the popular demand of the workers for 'the full proceeds of labour." 15

Here we seem to have pinned Engels down to a clear-cut statement regarding a crucial aspect of his position on distribution in his Communist society. But in this case is there not a severe conflict with Marx, who insisted in 1875 on the recognition of "unequal individual endowment and thus productive capacity of the workers as natural privileges"? Not if Marx intended specifically recognition of differentials reflecting "natural" characteristics, while Engels had in mind acquired characteristics involving training paid for by society as a whole. And this solution is the likely one since a primary purpose of Anti-Dühring was to refute the notion ascribed to Dühring of "natural" equality between individuals (pp. 88-99). ${ }^{16}$ Engels did allow that the "idea of equality" still play[ed] an important agitational role in the socialist movement of almost every country" (p. 95), but he insisted that the "real" or scientific content of the proletarian demand was strictly limited to "the abolition of classes" and went no further (p. 99). Claims beyond that were an "absurdity," considering the enormous range of individual character differences. And Engels cites Capital to the effect that the idea of equality "already possesses the fixity of a popular prejudice."

We conclude then that Engels' own insistence on equal pay under Communism must apply only to skills funded socially - in contrast to training funded privately under capitalismand, as with Marx, not to natural differences. What though of the ultimate Communist state? Workers-i.e. all members of society-would be paid at that future time not in terms of equal pay per hour whether the work is that of a porter or an architect as Dühring proposedalbeit presumptively at a "higher wage" than under capitalism - but on a completely different principle, since functional specialization would no longer exist (p. 186).

\section{The Allocative Role of the Free Market vs. Central Control}

A keen appreciation of the allocative function of markets is apparent in a variety of contexts, one of which provides a potent example of Marx's insistence on the constraint imposed by the market system on income-redistribution proposals. For Marx in Poverty of Philosophy (1847) rejected, on price-theoretic grounds and in terms of the dynamics of growth, the more specific proposals for State confiscation of rent by James Mill, Cherbuliez and Hilditch, which he represented as "a frank expression of the hatred the industrial capitalist bears towards the landed proprietor" (MECW 6:203). Apart from the complexity that "rent" often included interest paid to the landowner on capital incorporated in the land, land valuation indexes ("cadastres")—on which any confiscation would have to be basedcould not be taken as settled once-and-for-all, but were subject to continuous disturbance. Accordingly, "rent could not be the invariable index of the degree of fertility of the land, since every moment the modern application of chemistry is changing the nature of the soil and geological knowledge is just now in our days"- - here referring to the English eastern counties- "beginning to revolutionize all the old estimates of relative fertility;" moreover, 
"fertility is not so natural a quality as might be thought [but] is closely bound up with the social relations of the time. A piece of land may be very fertile for corn growing, and yet the market price may induce the cultivators to turn it into an artificial pastureland and thus render it infertile" (pp. 203-204). And in rejecting Proudhon's view of land as "capital which never perishes," Marx points out that "[1] and as capital is fixed capital; but fixed capital gets used up just as much as circulating capital. Improvements to the land need reproduction and upkeep.... There are even instances when land as capital might disappear even though the improvements remain incorporated in the land"- -such as the case when "rent proper is wiped out by the competition of new and more fertile soils" or when scarce improvements lose their value on becoming "universal owing to the development of agronomy" (p. 205). All of this pointed away from the static conception of rent attributed to Proudhon-his notion (in Marx's terms) of an "invariable index of the degree of the fertility of the land" (p. 203).

A striking instance of Marx's respect for the market is provided by a leading article in the New-York Daily Tribune condemning Napoleon III's plan to regulate bread prices throughout France (13 December 1858; MECW 16:110-114). Marx's objection turns on the array of further interventions that would be required to enforce the controls, drawing on the experience of Paris which had instituted them locally and where-at the end of the day- "the experiment proved a complete failure, the price of bread rising above the official maximum during the bad seasons, from 1855 to $1857 . . . "$ (p. 111). His forecast regarding the extension to France as a whole-as it applied in practice to "good years" and the maintenance of a price floor-emphasises the unthought-of consequences of the proposed measure including opportunities for "jobs and plunder" of all kinds:

By the artificial demand to be created through the means of three months' reserve, Napoleon tries to enhance prices artificially, and thus stop the mouth to agricultural France. On the other hand, he proclaims himself a sort of socialist providence to the proletarians of the towns, although in a rather awkward way, since the first palpable effect of his decree must be to make them pay more for their loaf then before. The "savior of property" shows the middle class that not even the formal intervention of his own mock Legislatures, but a simple personal ukase on his part, is all that is wanted to make free with their purses, dispose of municipal property, trouble the course of trade, and subject their monetary dealings to his private crochets. Lastly, the question is still to be considered from the pure Bonapartist point of view. Immense buildings for public granaries will become necessary over the whole of France; and what a fresh field they will open for jobs and plunder. An unexpected turn is also given to the trade in breadstuffs. What profits to be pocketed by the Crédit Mobilier and the other gambling companions of his Imperial Majesty! At all events, we may be sure that the Imperial Socialist will prove no more successful in raising the price of bread than he has been in attempts to reduce it (p. 114).

Over and again in his Poverty of Philosophy of 1847, republished by Engels in the German edition of 1885, Marx insisted on the demand component: "The exchange value of a product depends upon its abundance or its scarcity, but always in relation to demand" (MECW 6:115); Proudhon "has simply forgotten about demand, and that a thing can be 
scarce and abundant insofar as it is in demand" (p. 115); Proudhon's "abundance seems to be something spontaneous. He completely forgets that they are people who produce it, and that is in their interest never to lose sight of demand" (p. 116). As for the long-run, he forcefully rejected Proudhon's labour theory, and also the labour-based prices proposed for a Communist system:

Products will in future be exchanged in the exact ratio of the labour time they have cost. Whatever may be the proportion of supply to demand, the exchange of commodities will always be made as if they had been produced proportionately to the demand. Let M. Proudhon take it upon himself to formulate and lay down such a law, and we shall relieve him of the necessity of giving proofs. If, on the other hand, he insists on justifying his theory, not as a legislator, but as an economist, he will have to prove that the time needed to create a commodity indicates exactly the degree of its utility and marks its proportional relation to the demand, and in consequence, to the total amount of wealth. In this case, if a product is sold at a price equal to its cost of production, supply and demand will always be evenly balanced; for the cost of production is supposed to express the true relation between supply and demand (p. 132).

To return to M. Proudhon's thesis; since the labour time necessary for the production of an article is not the expression of its degree of utility, the exchange value of this same article, determined beforehand by the labour time embodied in it, can never regulate the correct relation of supply to demand, that is, the proportional relation in the sense M. Proudhon attributes to it at the moment (p. 134).

So much for the static level of conception. Capital movement between industries is dictated by alterations to demand-supply conditions:

It is not the sale of a given product at the price of its cost of production that constitutes the "proportional relation" of supply to demand, or the proportional quota of this product relatively to the sum total of production; it is the variations in demand and supply that show the producer what amount of a given commodity he must produce in order to receive at least the cost of production in exchange. And as these variations are continually occurring, there is also a continual movement of withdrawal and application of capital in the different branches of industry (p. 134).

It is historiographically significant that Marx should have cited here appreciatively passages from Ricardo on the operation of the allocation mechanism in response to deviations of market from cost price:

It is only in consequence of such variations, that capital is apportioned precisely, in the requisite abundance and no more, to the production of the different commodities which happen to be in demand. With the rise or fall of price, profits are elevated above, or depressed below their general level, and capital is either encouraged to enter into, or is warned to depart from the particular employment in which the variation has taken place ([Ricardo 1951-1973:88; Marx's emphasis). 
When we look to the markets of a large town, and observe how regularly they are supplied both with home and foreign commodities, in the quantity in which they are required, under all the circumstances of varying demand, arising from the caprice of taste, or a change in the amount of population, without often producing either the effects of a glut from a too abundant supply, or an enormously high price from the supply being unequal to the demand, we must confess that the principle which apportions capital to each trade in the precise amount than is required, is more active that is generally supposed [89-90] (134-135); Marx's emphasis).

These "neoclassical" themes are followed through with a vengeance by Engels. Appreciation of the allocative function of markets emerges strikingly in his Preface to his 1885 edition, where he attacks Rodbertus' version of labour money precisely because of its neglect of the competitive allocation mechanism. Thus, whereas Marx's labour-tickets fulfilled a cloakroom function only (see, note 10), Rodbertus' labour-tickets-according to Engels' account-allocated to workers in the various state industries, would circulate and be used freely to buy the commodities made available by the authority on the market at given labour-based prices, implying a degree of genuine consumer choice. Rodbertus maintained that all markets would clear on the basis of the planners" "calculation" relating to the number of labour tickets issued and the quantities of each type of good produced. It was to this scheme that Engels objected:

To desire, in a society of producers who exchange their commodities, to establish the determination of value by labour time, by forbidding competition to establish this determination of value through pressure on prices in the only way in which it can be established, is therefore merely to prove that, at least in this sphere, one has adopted the usual Utopian disdain of economic laws.

Secondly, competition, by bringing into operation the law of value of commodity production in a society of producers who exchange their commodities, precisely thereby brings about the only organization and arrangement of social production which is possible in the circumstances. Only through the undervaluation or overvaluation of products is it forcibly brought home to the individual commodity producers what society requires or does not require and in what amounts. But it is precisely this sole regulator that the Utopia advocated by Rodbertus among others wishes to abolish. And if we then ask what guarantee we have that [the] necessary quantity and not more of each product will be produced, that we shall not go hungry in regard to corn and meat while we are choked in beet sugar and drowned in potato spirit, that we shall not lack trousers to cover our nakedness while trouser buttons flood by the million-Rodbertus triumphantly shows us his famous calculation, according to which the correct certificate has been handed out for every superfluous pound of sugar, for every unsold barrel of spirit, for every unusable trouser button, a calculation which "works out" exactly, and according to which "all claims will be satisfied and the liquidation correctly brought about." And anyone who does not believe this can apply to the governmental chief revenue office accountant $\mathrm{X}$ in Pomerania, who has checked the calculation and found it correct, and who, as one who has never yet been caught lacking with the accounts, is thoroughly trustworthy (MECW 26:287-288; italics added). 
Hutchison is amazed that Engels would have condemned Rodbertus while neglecting to raise the same, or indeed any other, objection against Communist organization, feeling no "intellectual or moral obligation to give some thought to the kind of economic organization which would, or could, follow" the demise of capitalism (1981:14). ${ }^{17}$ Hutchison is too harsh. Engels' complaint, as it emerges in the above passage, is that Rodbertus retained significant features of a market system yet rejected the competitive pricing mechanism. A similar complaint is addressed against Dühring - that he wished to retain elements of the market system yet preclude its effective operation (MECW 25:275). This to Engels was an unacceptable halfway house. Like Marx, he perceived of a system excluding markets, one involving centralised decisions on investment, output and pay and-so it seems from the contrast with Rodbertus - consumer rationing.

Also in Anti-Dühring (1878) — a work approved of by Marx and to which he contributed (Section 3) - it emerges that in Communist society excluding money and markets, direct procedures suffice to arrive at labour embodiments. The indirect procedures of capitalism involving reference to money prices are avoided by "direct social production and direct distribution [which] preclude all exchange of commodities, therefore also the transformation of the products into commodities (at any rate within the community), ${ }^{18}$ and consequently also their transformation into values" (MECW 25:294). The entire notion of value in fact becomes irrelevant. ${ }^{19}$ All this is confirmed by further reference to such a society's direct calculation of the labour time required in the production of, say, "a steam-engine... or a hundred square yards of cloth of a certain quality" without reference to any "third product" acting as some sort of measure of value:

From the moment when society enters into possession of the means of product and uses them in direct association for production, the labour of each individual, however varied its specifically useful character may be, becomes at the start and directly social labour. The quantity of social labour contained in a product need not then be established in a roundabout way; daily experience shows in a direct way how much of it is required on the average. Society can simply calculate how many hours of labour are contained in a steam-engine, a bushel of wheat of the last harvest, or a hundred square yards of cloth of a certain quality. It could therefore never occur to it still to express the quantities of labour put into the products, quantities which it will then know directly and in their absolute amounts, in a third product, in a measure which, besides, is only relative, fluctuating, inadequate, though formerly unavoidable for lack of a better one, rather than express them in their natural, adequate and absolute measure, time... Hence, on the assumption that we made above, society will not assign values to products. It will not express the simple fact that the hundred square yards of cloth have required for their production, say, a thousand hours of labour in the oblique and meaningless way, stating that they have the value of a thousand hours of labour. ${ }^{20}$

Fully to appreciate the position in Anti-Dühring we must keep in mind a concern that to permit money to circulate would inevitably lead to a reemergence of Capitalist organization. For example, Dühring's money did not act as "a mere labour certificate" but fulfilled a genuine "monetary" function as far as concerns private saving with potentially devastating consequences: 
Herr Dühring gives everyone a right to "quantitatively equal consumption" ..., but he cannot compel anyone to exercise it. On the contrary, he is proud that in the world he has created everyone can do what he likes with his money. He therefore cannot prevent some from setting aside a small money hoard, while others are unable to make ends meet on the wage paid to them. He even makes this inevitable by explicitly recognising in the right of inheritance that family property should be owned in common; whence comes also the obligation of the parents to maintain their children. But this makes a wide breach in quantitatively equal consumption. The bachelor lives like a lord, happy and content with his eight or twelve marks a day, while the widower with eight minor children finds it very difficulty to manage on this sum. On the other hand, by accepting money in payment without any question, the commune leaves open the door to the possibility that this money may have been obtained otherwise than by the individual's own labour... . The commune does not know where it comes from. But in this way all conditions are created permitting metallic money, which hitherto played the role of a mere labour certificate, to exercise its real money function. Both the opportunity and the motive are present, on the one hand to form a hoard, and on the other to run into debt. The needy individual borrows from the individual who builds up a hoard. The borrowed money, accepted by the commune in payment for means of subsistence, once more becomes what it is in present-day society, the social incarnation of human labour, the real measure of labour, the general medium of circulation. All the "laws and administrative regulations" ... in the world are just as powerless against it as they are against the multiplication table or the chemical composition of water. And as the builder of the hoard is in a position to extort interest from people in need, usury is restored along with metallic money functioning as money (pp. 289290).

The retention of money as means of purchase and payment in international trade aggravated the private motive to accumulate and, with it, the demise of the entire commune system:

Up to this point we have only considered the effects of a retention of metallic money within the field of operation of the Dühring economic commune. But outside this field the rest of the world, the profligate world, meanwhile carries on contentedly in the old accustomed way. On the world market gold and silver remain world money, a general means of purchase and payment, the absolute social embodiment of wealth. And this property of the precious metal gives the individual members of the economic communes a new motive to accumulate a hoard, get rich, exact usury; the motive to manoeuvre freely and independently with regard to the commune and beyond its borders, and to realise on the world market the private wealth which they have accumulated. The usurers are transformed into dealers in the medium of circulation, bankers, controllers of the medium of circulation and of world money, and thus into controllers of the means of production, even though these may still for many years be registered nominally as the property of the economic and trading communes. And so that hoarders and usurers, transformed into bankers, become the masters also of the economic and trading communes themselves (p. 290). 
We turn now to proposals regarding consumer demand. Direct calculation-involving mainly but not only labour inputs as we shall see-is fundamental to the planning process envisaged, given the pattern of consumption:

It is true that even then it will still be necessary for society to know how much labour each article of consumption requires for its production. It will have to arrange its plan of production in accordance with its means of production, which include, in particular, its labour-powers. The useful effects of the various articles of consumption, compared with one another and with the quantities of labour required for their production, will in the end determine the plan. People will be able to manage everything very simply, without the intervention of much-vaunted "value" (pp. 294-295). ${ }^{21}$

Whence the assumed pattern of consumption? Since nothing more is said regarding consumer demand one is invited to conclude that it too is decided upon directly by the central planners. This in fact is my impression. It is unlikely that Engels had in mind freedom of consumer choice when, a little earlier in the text, he compared the "social anarchy of production" as it existed, with the "social regulation of production upon a definite plan according to the needs of the community and of each individual," referring here to "direct social appropriation, as means to the maintenance and extension of production" (investment) and "direct individual appropriation, as means of subsistence and enjoyment" (consumption) (267; emphasis added). After all, he had been expatiating on the anarchical character of capitalist production due in part to ignorance of markets: "No one knows how much of his particular article is coming on the market, nor how much of it will be wanted. No one knows whether his individual product will meet an actual demand, whether he will be able to make good his costs of production or even to sell his commodity at all" (p. 259). The solution to the enormous waste of resources under capitalism with an eye to cyclical instability in particular lay precisely in "the socialized appropriation of the means of production":

This solution can only consist in the practical recognition of the social nature of the modern forces of production, and therefore in the harmonising of the modes of production, appropriation, and exchange with the socialised character of the means of production. And this can only come about by society openly and directly taking possession of the productive forces which have outgrown all control except that of society as a whole. The social character of the means of production and of the products today reacts against the producers, periodically disrupts all production and exchange, acts only like a law of nature working blindly forcibly, destructively. But with the taking over by society of the productive forces, the social character of the means of production and of the products will be utilised by the producers with a perfect understanding of its nature and instead of being a source of disturbance and periodical collapse, will become the most powerful lever of production itself (p. 266).

All this, one should note, repeats what appeared in the Outlines of 1844 (MECW 3:434), that ignorance of the pattern of consumption was the source of "periodic upheavals" under capitalism, in contrast to the Communist solution: "If the producers as such knew how much the consumers required, if they were to organise production, if they were to share it out 
amongst themselves, then the fluctuations of competition and its tendency to crisis would be impossible." This link between 1878 and 1844 is significant since Engels himself refers readers back to the former work. "As long ago as 1844 I stated that the above-mentioned balancing of useful effects and expenditure of labour on making decisions concerning production was all that would be left, in a communist society, of the politico-economic concept of value..." (MECW 25:295n). ${ }^{22}$ And he seems to answer our question-Whence the given pattern of consumption that is taken for granted?-for the allusion here is apparently to communal decision-making regarding production based on "inherent utility" rather than personal judgement:

Value is the relation of production costs to utility. The first application of value is the decision as to whether a thing ought to be produced at all; i.e., as to whether utility counterbalances production costs. Only then can one talk of the application of value to exchange. The production costs of two objects being equal, the deciding factor determining their comparative value will be utility.

This basis is the only just basis of exchange. But if one proceeds from this basis, who is to decide the utility of the object? The mere opinion of the parties concerned? Then in any event one will be cheated. Or are we to assume a determination grounded in the inherent utility of the object independent of the parties concerned, and not apparent to them? If so, the exchange can only be effected by coercion, and each party considers itself cheated. The contradiction between the real inherent utility of the thing and the determination of that utility, between the determination of utility and the freedom of those who exchange, cannot be superseded without superseding private property; and once this is superseded, there can no longer be any question of exchange as it exists at present. The practical application of the concept of value will then be increasingly confined to the decision about production, and that is its proper sphere (MECW 3:426). ${ }^{23}$

As mentioned, the position of Anti-Dühring was approved of by Marx. Marx himself in scattered comments, implies communal decisions regarding the allocation of consumption goods. It is suggested by the formulation whereby the vouchers distributed to workers "entitl[ed] them to withdraw from the social supplies of consumer goods a quantity corresponding to their labour time" (see, note 10). And in Poverty of Philosophy, we find it asserted that "[i]n a future society, in which class antagonism will have ceased, in which there will no longer be any classes, use will no longer be determined by the minimum time of production; but the time of production devoted to an article will be determined by the degree of its social utility" (MECW 6:134). ${ }^{24}$

If our interpretation is accurate it becomes easier to understand how, in the absence of money and markets, the actual allocation of consumer goods was to be accomplished. ${ }^{25}$ What was apparently envisaged is a sort of "war economy" entailing the production of goods selected by the planners, and allocated according to workers' claims based on their labour contributions - perhaps rights to a bundle of goods is what was envisaged-account taken of natural-skill differentials (see, p. 24, regarding autarky). The objections to Rodbertus' labour-ticket scheme also point in this direction (see, p. 19). 
All this reduces the force of Hutchison's criticisms. Even so, there remains the naïve belief that the planners were capable of making accurate estimates of the labour inputs required, and the distribution of labour-tickets according to the pay differentials permitted and corresponding consumption quotas - that all this could be achieved, as Engels thought, "very simply." In point of fact, the planning task envisaged is rather more complex than we have so far suggested, for planners would have to make allowance in their cost calculations, as shadow or accounting returns, for interest and rent based on the productivity contribution of land and capital and not only for labour. Engels insisted on this as early as 1844:

If. . . we abandon private property, rent is reduced to its truth, to the rational notion which essentially lies at its root. The value of the land divorced from it as rent then reverts to the land itself. This value, to be measured by the productivity of equal areas of land subjected to equal applications of labour, is indeed taken into account as part of the production costs when determining the value of products; and like rent, it is the relation of productivity to competition-but to true competition, such as will be developed when its time comes (MECW 3:430; emphasis added).

If we abandon private property, then all these unnatural divisions [attributed to capitalism] disappear. The difference between interest and profit disappears; capital is nothing without labour, without movement. The significance of profit is reduced to the weight which capital carries in the determination of the costs of production; and profit thus remains inherent in capital, in the same way as capital itself reverts to its original unity with labour (431; emphasis added). ${ }^{26}$

Indeed costs would include an allowance for "science": "But in a rational order which has gone beyond the division of interests as it is found with the economist, the mental element certainly belongs among the elements of production and will finds it place, too, in economics among the costs of production" (p. 427).

We have suggested that the system envisaged was in effect one of war economy. And this is further indicated by a document, composed by Engels at about the same time as Anti-Dühring, entitled "American Food and the Land Question." Here he describes the American "revolution in farming, together with the revolutionised means of transport as invented by the Americans" which exported wheat to Europe "at such low prices that no European farmer can compete with it-at least not while he is expected to pay rent"; and which together with the prospect of similar development in Russia and the Argentine-_"all lands equally fit for this modem system of giant farming and cheap production" - could be expected to undermine European agriculture (The Labour Standard, July 2 1881, MECW 24:398-399). The "upshot of all this," he predicts, "will and must be that it will force upon us the nationalisation of the land and its cultivation by co-operative societies under national control. Then, and then alone, it will again pay both the cultivators and the nation to work it, whatever the price of American or any other corn and meat may be" (p. 399). Engel thus envisaged an autarkic régime, with activity—at least agriculture—organized by "cooperatives" under "national control" suggesting no inter-cooperative competition. ${ }^{27}$ All this does not imply a failure to appreciate the operation of the market system. It was understood only too well. 
In evaluating further the validity of Hutchison's charges we must of course not forget the efficiency losses attributed to the market system, due particularly to the "anarchical" dimension elucidated above relating to cyclical instability that would be eliminated by "systematic definite organization" (MECW 25:270). And to this we add other potential sources of increased efficiency under Communism, for one that "it sets free for the community at large a mass of means of production and of products, by doing away with the senseless extravagance of the ruling classes of today and their political representatives" (p. 269). Engels and Marx put more weight on the gains to be expected from abolition of markets than on the loss of a signalling device that would, they envisaged, be replaced by effective central direction.

\section{Some Unexpected Parallels}

The position of Marx and Engels on distribution turns out in significant respects to be akin to that of the "classical liberal" economists Hayek and Mises. Of course, Marx predicted the collapse of capitalism and championed arrangements involving inter alia the abolition of money; I am not obviously identifying Marx with Mises and Hayek, only pointing to certain specific parallels reflecting the common ground that the capitalist system should not be tampered with, albeit for very different reasons. ${ }^{28}$

Consider the incessant rejection by Engels and Marx of approaches to distribution under capitalism based on moral criteria relating to "fairness." Such criteria are represented as short-sighted prejudice-deriving from the competitive experience-having no absolute justification (see, pp. 6-7; also pp. 14-15). This was Friedrich von Hayek's position too, as expressed in The Road to Serfdom:

Most people find it difficult to admit that we do not possess moral standards which would enable us to settle these questions-if not perfectly, at least to greater general satisfaction than is done by the competitive system. Have we not all some idea of what is a "just price" or a "fair wage"? Can we not rely on the strong sense of fairness of the people? And even if we do not now agree fully on what is just or fair in a particular case, would popular ideas not soon consolidate into more definite standards if people were given an opportunity to see their ideals realized?

Unfortunately, there is little ground for such hopes. What standards we have are derived from the competitive regime we have known and would necessarily disappear soon after the disappearance of competition. What we mean by a just price, or a fair wage is either the customary price or wage, the return which past experience has made people expect, or the price or wage that would exist if there were no monopolistic exploitation (1944:110-111). ${ }^{29}$

Hayek goes on to consider the claim for wage payments according to "the 'full produce of ... labour,' to which so much of socialist doctrine traces back;" and he commends the general rejection by contemporary socialists of such a claim (p. 111). But we have seen that this too was precisely the position adopted by Marx in his polemic against the program of the 
German Workers Party, and his own insistence on labour "inequality" under Communism (Section 2.3).

There are also parallels with Ludwig von Mises. Permanent improvement in the living standards of the masses required, Mises insisted, increased accumulation per capita-the standard "classical" position of course. There were no short cuts: "The only means to raise wage rates permanently for all those seeking jobs and eager to earn wages is to raise the productivity of the industrial effort by increasing the per-head quota of capital invested" (1980 [1950]:27-28). And to the contrary, intervention in the price system to alter distribution in labour's favour could only harm national economic performance: "Minimum wage rates, whether decreed and enforced by the government or by labor union pressure and violence, result in mass unemployment prolonged year after year as soon as they try to raise wage rates above the height of the unhampered market" (p. 27). On the matter of direct interference with the pattern of distribution he was very clear regarding the damage to productivity that would result:

The philosophy underlying the system of progressive taxation is that the income and the wealth of the well-to-do classes can be freely tapped. What the advocates of these tax rates fail to realize is that the greater part of the incomes taxed away would not have been consumed but saved and invested. In fact, this fiscal policy does not only prevent the further accumulation of new capital. It brings about capital decumulation (p. 32).

That economic performance and distribution are intimately connected was, we have shown in Section 2, insisted on by Marx and Engels; for them too distribution problems could not be dealt with independently of production for precisely the same reasons as those offered by Mises. ${ }^{30}$ This position clashes with the formal contrast drawn by J.S. Mill between "immutable" Laws of Production and "malleable" Laws of Distribution; if we take this contrast seriously there is more scope for income redistribution without endangering productive capacity in the Mill scheme of things. I doubt though that we should read Mill literally (Hollander 1985:216-222); it is certainly the case that he too opposed progressive taxation of earned income on grounds of incentive with particular reference to accumulation (pp. 859-860).

I turn now to the "binary" approach to systems that emerges both in Engels and Marx and in Mises - their insistence on "pure" communism and "pure" capitalism respectively the common position that there is no half-way house between fully-fledged capitalism and central control.

As for Marx an excellent instance of his concerns in this regard is provided by a letter of 1859 objecting to the "Proudhonist socialism now FASHIONABLE in France"-that it "wants to retain private production while organising the exchange of private products, to have commodities but not money.... Communism must above all rid itself of this 'false brother" (1 February 1859, to Joseph Weydemeyer; MECW 40:377). And as we know, Marx and Engels were fearful that to tolerate money and markets to any extent would inevitably undermine any Communist social structure (see, pp. 20-21). ${ }^{31}$ The position implicitly attributes to the capitalist system a robustness which seems to conflict with the confident predictions regarding its more-or-less immanent collapse. As for the toleration 
of a capitalist sector (and also the progressive income-tax proposals) in the Principles of Communism and the Communist Manifesto (see, pp. 31-32), we must not forget the explicit assumption of firm communist political control-the police no less-to beat back any incipient degeneration.

My concern now is not Marxian consistency, but the parallel with Mises who in his famous 1950 address "Middle-of-the Road Policy Leads to Socialism" also rejected halfway houses. ${ }^{32}$ Mises sets out by denying that the essential dispute between socialism and capitalism relates to the distribution of the national dividend between wage earners and capitalists (1980 [1950]:19-20), a position shared with Marx and Engels who downplayed the distribution problem as we know (see e.g., p. 9, p. 15). The antagonism between systems had a much deeper source:

The antagonism between capitalism and socialism is not a dispute about the distribution of booty. It is a controversy about which of two schemes for society's economic organization, capitalism or socialism, is conducive to the better attainment of those ends which all people consider as the ultimate aim of activities commonly called economic, viz., the best possible supply of useful commodities and services. Capitalism wants to attain these ends by private enterprise and initiative, subject to the supremacy of the public's buying and abstention from buying on the market. The socialists want to substitute the unique plan of a central authority for the plans of the various individuals. They want to put in place of what Marx called the "anarchy of production" the exclusive monopoly of the government. The antagonism does not refer to the mode of distributing a fixed amount of amenities. It refers to the mode of producing all those goods which people want to enjoy (1980 [1950]:20). ${ }^{33}$

For Mises, "[t]he conflict of the two principles is irreconcilable and does not allow of any compromise. Control is indivisible. Either the consumers' demand as manifested on the market decides for what purposes and how the factors of production should be employed, or the government takes care of these matters. There is nothing that could mitigate the opposition between these two contradictory principles. They preclude each other" (pp. 20-21). "Interventionism" thus could not be considered "a permanent system of society's economic organization," one which "retain[s] private ownership of the means of production, entrepreneurship and market exchange" but subjects it to government regulation (p. 21). Again: "The middle-of-the-road policy is not an economic system that can last. It is a method for the realization of socialism by installments" (pp. 32-33). ${ }^{34}$ A classic instance of what Mises feared is provided by a price maximum imposed on the price of milk. To render such intervention effective would, runs the argument, ultimately require control of the prices of all consumers' goods and of all factors of production: "But when this state of all-round control of business is attained, there can no longer be any question of a market economy. No longer do the citizens by their buying and abstention from buying determine what should be produced and how. The power to decide these matters has devolved upon the government. This is no longer capitalism; it is all-round planning by the government, it is socialism" (p. 24). The formal retention of private ownership of productive means, prices, wages, interest rates and profits is meaningless since they are determined by authority with the government not consumers directing production. "It is the Zwangswirtschaft of Hitler's 
German Reich, and the planned economy of Great Britain" (pp. 24-25). ${ }^{35}$ As the matter is summarized in the 1947 formulation:

Men must choose between the market economy and socialism. The state can preserve the market economy in protecting life, health and private property against violent or fraudulent aggression; or it can itself control the conduct of all production activities. Some agency must determine what should be produced. If it is not the consumers by means of demand and supply on the market, it must be the government by compulsion (Mises 1947:34).

This denial of a stable middle solution between systems is held in common with Marx and Engels with this difference, that Mises' concern was the fragility of capitalism and that of Marx and Engels the fragility of communism. Nonetheless, Marx's technical analysis of the control of bread prices (see, p. 17) is wholly in line with that of Mises.

Hayek too in his paper "Pricing versus Rationing" (1939) takes a similar position:

It will be sufficiently evident that rationing, if it is not to lead to grave waste, would involve little less than central planning of all production in every detail. Not only all the "scarce" resources but their substitutes as well would have to be planned and controlled by some central authority. If one thing has been definitely established with regard to a planned or socialist system, it is that to stop halfway will only destroy the efficiency of the competitive mechanism without realizing any of the supposed advantages of a planned system (1997 [1939]:155).

Yet there is some evidence that he did not go quite as far as Mises regarding the "fragility" of the market system. ${ }^{36}$ All in all, Hayek was concerned with "the process through which certain kinds of measures can destroy the bases of an economy based on the market and gradually smother the creative powers of a free civilization . . ." (emphasis added), but insisted that his "was not... an exhortation to resistance against any improvement or experimentation" (1944:x). He here had in mind the test provided by the Rule of Law, the principle that "government in all its actions is bound by rules fixed and announced beforehand," thus reducing to a minimum "the discretion left to the executive organs wielding coercive power," and avoiding "stultifying individual efforts by ad hoc action" (72-73; see also 1960). ${ }^{37}$ The parallels we have encountered seem to be more marked between Marx and Mises than between Marx and Hayek.

Of particular significance for our present theme relating to "unexpected parallels" is Engels' insistance on the coordination function of markets in his criticism of Rodbertus' labour money (see, pp. 19-20), of which Hutchison has said without exaggeration that "Mises and Hayek could hardly have made the point more forcefully" (1981:15). And finally, note should here also be taken of an important observation by Vaughn regarding Hayek's emphasis on the limits of human knowledge in his technical essays on socialist planning:

Hayek was challenging not only the economics of central planning, but a particular way of conceptualizing economic theory. Economic planning requires not only the 
centralization of knowledge, but also the ability to identify what knowledge is worth centralizing. Yet Hayek believed that most economically useful knowledge is local, detailed, implicit and changeable. What kind of political economy-indeed what kind of economic theory-is relevant when economic actors possess knowledge like that? (Vaughn 1998:236).

It is precisely this perspective on "local, detailed, implicit and changeable" knowledge that in part determined Marx's rejection of rent-confiscation schemes-the State did not have such knowledge (see, pp. 16-17). We were obliged in responding to Hutchison's charges, it will be recalled, to seek to understand the support for Central Control considering the Engels-Marx appreciation of the competitive market process. The solution we proposed lies in their presumption that such a sophisticated allocative device would be unnecessary under the simplified regime envisaged.

\section{An Overview: The Evolutionary Dimension}

The necessitarian logic behind the concept of Historical Materialism has often been remarked on, with reference to growing immizeration, wealth and income inequality, cyclical instability, centralization and so forth leading to revolution (see the recent account in Baumol 2001). The general evolutionary theme is nicely stated by Marx in the Economic Manuscripts of 1861-1863 with respect to the dissolution of capitalism:

This is an essentially different conception from that of the bourgeois political economists, themselves imprisoned in capitalist preconceptions, who are admittedly able to see how production is carried on within the capital-relation, but not how this relation is itself produced, and how at the same time the material conditions for its dissolution are produced within it, thereby removing its historical justification as $a$ necessary form of economic development, of the production of social wealth (MECW 34:466).

Particularly important are specific observations in Capital III, composed in the 1860s, regarding the joint-stock company- "the ultimate development of capitalist production" (MECW 37:434) —as a transitional form from private to social organization:

The capital, which in itself rests on a social mode of production and presupposes a social concentration of means of production and labour power, is here directly endowed with the form of social capital (capital of directly associated individuals) as distinct from private capital, and its undertakings assume the form of social undertakings as distinct from private undertakings. It is the abolition of capital as private property within the framework of the capitalist mode of production itself.

The part played by credit is much emphasized in this context and also with respect to the growth of cooperative factories: 
They show how a new mode of production naturally grows out of an old one, when the development of the material forces of production and of the corresponding forms of social production have reached a particular state. Without the factory system arising out of the capitalist mode of production there could have been no cooperative factories. Nor could these have developed without the credit system arising out of the same mode of production. The credit system is not only the principle basis for the gradual transformation of capitalist private enterprises into capitalist stock companies, but equally offers the means for the gradual extension of cooperative enterprises on a more or less national scale. The capitalist stock companies, as much as the cooperative factories, should be considered as transitional forms from the capitalist mode of production to the associated one, with the only distinction that the antagonism is resolved negatively in the one and positively in the other (p. 438).

This theme is rehearsed by Engels in 1878 with a focus on the evolution from joint-stock organization to prospective nationalization of industry and "direction of production" by the Capitalist State:

The fact that the socialised organisation of production within the factory has developed so far that it has become incompatible with the anarchy of production in society, which exists side by side with and dominates it, is brought home to the capitalists themselves by the violent concentration of capital that occurs during crises, through the ruin of many large, and a still greater number of small capitalists.... The period of industrial high pressure, with its unbounded inflation of credit, not less than the crash itself, by the collapse of great capitalist establishments, tends to bring about that form of the socialisation of great masses of means of production which we meet with in the different kinds of joint-stock companies. Many of these means of production and of communication are, from the outset, so colossal that, like the railways, they exclude all other forms of capitalistic exploitation. At a further stage of evolution this form also becomes insufficient: the official representative of capitalist society-the state - will ultimately have to undertake the direction of production. This necessity for conversion into state property is felt first in the great institutions for intercourse and communication - the post office, the telegraphs, the railways (Anti-Dühring; MECW $25: 264-265) .^{38}$

Engels refers to the prospective extension of State control as a natural, not a forced, matter arising from the logic of the situation which explains his representation of Bismarckian forms of "state-ownership of industrial establishments" as "a kind of spurious socialism" (p. $265 n$ ). And though even "natural" extensions of State control occurred without disturbing "the capitalist relation" insofar as "the workers remain wage-workers," it is part of the process whereby the ultimate "solution" to class conflict would be achieved:

But the transformation, either into joint-stock companies, or into state ownership, does not do away with the capitalistic nature of the productive forces. In the jointstock companies this is obvious. And the modern state, again, is only the organisation that bourgeois society takes on in order to support the general external conditions of 
the capitalist mode of production against the encroachments as well of the workers as of individual capitalists. The modern state, no matter what its form, is essentially a capitalist machine, the state of the capitalists, the ideal personification of the total national capital. The more it proceeds to the taking over of productive forces, the more does it actually become the national capitalist, the more citizens does it exploit. The workers remain wage-workers-proletarians. The capitalist relation is not done away with. It is rather brought to a head. But, brought to a head, it topples over. State ownership of the productive forces is not the solution of the conflict, but concealed within it are the technical conditions that form the elements of that solution (pp. 265-266).

By "the elements of the solution" provided by nationalization of industry on the part of the capitalist state is intended, partly, that the proletarians —once they seize power-will have been "shown the way" to proceed with a well-established exemplar at hand:

Whilst the capitalist mode of production more and more completely transforms the great majority of the population into proletarians, it creates the power which, under penalty of its own destruction, is forced to accomplish this revolution. Whilst it forces on more and more the transformation of the vast means of production, already socialised, into state property, it shows itself the way to accomplishing this revolution. The proletariat seizes political power and turns the means of production in the first instance into state property (p. 267).

Here we have a splendid illustration of Engels' belief that the tasks of Scientific Socialism included its revelation of "the elements [within Capitalism] of the future new organisation of production and exchange which will put an end to ... abuses" (see, p. 14).

The evolutionary dimension extends much further. The very term Communist Revolution is misleading except insofar as it relates to the acquisition and maintenance of political power by the proletariat. Thus we have Marx's "political transition period in which the State can be nothing but the revolutionary dictatorship of the proletariat" (see, note 8); and Engels' legitimization of "terror" by the revolutionary party against the "reactionaries" " $O n$ Authority," 1874; MECW 23:425), and the role he accorded the proletarian state in "keeping down its enemies" (letter to August Bebel, March 1875; MECW 24:71). ${ }^{39}$ The notion of Revolution must be strictly qualified if applied to economics. It is true that much of Engels' Principles of Communism (1847) implies that the foundations for a social transformation, manifested in enormous productive capacity, were actually in place, allowing communist society "to increase these productive forces in a short time to an infinite extent" (MECW 6: 348f). Yet he answers Question 17: "Will it be possible to abolish private property at one stroke?" firmly in the negative:

No, such a thing would be just as impossible as at one stroke to increase the existing productive forces to the degree necessary for instituting community of property. Hence, the proletarian revolution, which in all probability is impending, will transform existing society only gradually, and be able to abolish private property only when the necessary quantity of the means of production has been created (p. 350). 
It is an extraordinary concession to insist on the retention of private-property institutions after the achievement of proletarian political rule, in order to assure that degree of expansion of productive capacity required for the successful implementation of fully-fledged communism. This position is confirmed by Engels' insistence on the "gradual expropriation of landed proprietors, factory owners, railway and shipping magnates," with the further remarkable qualification that it be done "partly through competition on the part of state industry and partly through compensation in assignations" (emphasis added). ${ }^{40}$ In Marx's version too in the Communist Manifesto, "the proletariat will use its political supremacy to wrest, by degrees, all capital from the bourgeoisie ..." (MECW, 6:504; emphasis added). The "radical onslaught upon private ownership," as Engels put it, is much less radical than one is initially led to believe.

It would, of course, entail fine judgment to specify the rate at which the capitalist sector might be safely dismantled by the communist régime. The same applies to the progressive taxation and related proposals whose specific purpose was to whittle away capitalism after the communist take-over. ${ }^{41}$ Marx and Engels evidently relied on the ability of the new rulers not to compromise the hoped-for performance by the residual capitalist sector in creating the capacity required to assure the successful implementation of fully-fledged communism.

Also relevant to the evolutionary theme are the further developments envisaged once the private-property system had been entirely eliminated. I refer again to Marx's "first phase" and "higher phase" of communism. We have thus seen that in the first phase-as the system has emerged out of Capitalism-wage inequality is to be recognized; only in the later phase would the egalitarian principle apply: "From each according to his abilities to each according to his needs." And there is Engels' express statement that his own and Marx's support for "cooperatives" applied only to a transitional arrangement (see, note 27).

I have at last arrived at my conclusion - that violent transition between economic systems and within systems is rejected by Marx and Engels in favour of caution. It is an impressive insight to have emphasized transitional problems, one that might have served as a red flag for our modern-day advisors and their clients who have rushed to dismantle control systems with the inevitable outcome - already clear to Smith and Ricardo when they, in their day, evaluated proposals to abandon various forms of contemporary control. ${ }^{42}$

\section{Appendix: Mises on Marx}

The history of post-Marx Communism is one of "evolution" versus "revolution" as the legitimate path to the future, Marx himself more often than not envisaged as championing a revolutionary road. For example, the Erfurt Program of 1891, due largely to Karl Kautsky, has been described as "mark[ing] a return to the more revolutionary, and hence more purely Marxian, socialist vision" compared to the Gotha Program of 1875, while Edward Bernstein reversed directions in his Evolutionary Socialism of 1909 (1899) (Caldwell 1997:2-3). And there is on-going debate regarding Lenin-whether and how his program was faithful to Marx (see e.g., Service 2000:5).

I have argued that the Gotha Program was in fact too revolutionary for Marx. Here I wish to point to a "solution" offered by Mises, who distinguishes what he calls Marx's "plan 
for the step-by-step transformation of capitalism into socialism" of the Manifesto with the position in Capital: ${ }^{43}$

Karl Marx and Frederick Engels recommended successively each of . . two ways for the realization of socialism. In 1848, in the Communist Manifesto, they outlined a plan for the step-by-step transformation of capitalism into socialism. The proletariat should be raised to the position of the ruling class and use its political supremacy "to wrest, by degrees, all capital from the bourgeoisie." This, they declare, "cannot be effected except by means of despotic inroads on the rights of property and on the conditions of bourgeois production; by means of measures, therefore, which appear economically insufficient and untenable, but which in the course of the movement outstrip themselves, necessitate further inroads upon the old social order, and are unavoidable as a means of entirely revolutionizing the mode of production." In this vein they enumerate by way of example ten measures.

In later years, Marx and Engels changed their minds. In his main treatise, Das Kapital, first published in 1867, Marx saw things in a different way. Socialism is bound to come "with the inexorability of a law of nature." But it cannot appear before capitalism has reached its full maturity. There is but one road to the collapse of capitalism, namely the progressive evolution of capitalism itself. Then only will the great final revolt of the working class give it the finishing stroke and inaugurate the everlasting age of abundance (1980 [1950]:28-29). ${ }^{44}$

Now there are problems with Mises' contrast. It cannot be taken for granted that Marx in Capital intended a literal once-and-for-all transition by his dramatic declarations that the "knell of capitalist private property sounds," or that "the expropriators are expropriated."45 There is no necessary conflict with the Communist Manifesto where the achievement of Communist political power - the Revolution no less - is itself envisaged as coming at the appropriate time in the course of capitalist development "with the inexorability of a law of nature," and yet where Marx was explicit that the capitalist structure could not be abolished "at one stroke." 46

Another aspect of the contrast is questionable. Mises designates Marx's position in Capital as opposed to reforms on the grounds that they are in effect reactionary:

From the point of view of this later doctrine Marx and the school of orthodox Marxism reject all policies that pretend to restrain, to regulate and to improve capitalism. Such policies, they declare, are not only futile, but outright harmful. For they rather delay the coming of age of capitalism, its maturity, and thereby also its collapse. They are therefore not progressive, but reactionary (p. 29).

But the notion that the position in 1848 was more progressive is misleading. As emphasized in our text, all the "reforms" recommended in 1848 presume the Communist Party to be in firm control. It is highly unlikely, for example, that a steeply progressive income tax would have been recommended in 1848 for the capitalist system. 


\section{Acknowledgments}

I thank the participants at a Ben-Gurion University departmental seminar 9 May 2001; a University of Nice seminar 20 June 2001; the Summer School in the History of Economic Thought, George Mason University 13 July 2001; and Peter Boettke's Political Economy Seminar at George Mason University, 2 November 2001. This paper, in an earlier version, was presented at the History of Economics Society meetings, Atlanta 4 January 2002. I am particularly indebted to Bridget Butkevich, John Davis, Ragip Ege, Andrew Farrant, David Levy and Joe Persky for their generous and helpful criticisms.

\section{Notes}

1. Engels' Principles of Communism, and the Communist Manifesto are shown below to apply to an earlier period involving communist political control but allowance for a residual private sector. The Socialist phase, by contrast, entails fully-fledge public ownership and central control.

2. John Davis has brought to my attention debate over the status of moral standards in Marx's analysis: whether post-capitalist moral standards can be used to evaluate capitalism (represented to some extent in the actual proletarian form of consciousness) consistently with the perspective on morals as reflecting the ruling mode of production. (See, for example, Tucker 1969 and Wood 1972 on the position that moral standards are determined uniquely in terms of the mode of production; and Husami 1978 for the alternative position.) Even if one accepts that reference to post-capitalist standards-such as that encapsulated in the rule "from each according to his abilities, to each according to his needs"-is almost certainly in the background as an ultimate ideal, this was not made the basis of the public case for socialism as will now become clear.

3. MECW throughout this paper refers to the Marx-Engels Collected Works. New York: International Publishers.

4. Marx's objection that Proudhon had failed to appreciate the source and nature of non-labour income is striking, since the 1844 documents had actually commended Qu'est que la proprieté (1840) for hitting upon a notion of surplus value in a private-property system.

5. Marx seems implicitly to assume throughout differential savings propensities between classes.

6. In his "Wages," at this same period, Marx had written of the "crazy relationship" between capital and labour, in the light of which "all Fourierist and other attempts at mediation"- an obvious allusion to redistribution measures-"appear in their true absurdity" (MECW 6:429).

7. The "inequality" in question refers specifically to labour's claim to private consumption goods or "individual means of consumption" (see below, p. 12). Other sources of inequality would be eliminated in Communist society considering the absence of private ownership of land and capital.

8. Marx specifically refers to the circumstance that "[b]etween capitalist and communist society lies the period of the revolutionary transformation of the one into the other," corresponding to which "is also a political transition period in which the stage can be nothing but the revolutionary dictatorship of the proletariat" (p. 95). He points out that the Gotha Programme "deals neither with this nor with the future state of communist society." On the "period of transition," see Duncan (1973:170-181).

9. See, note 27 for a similar conclusion regarding Engels on cooperation.

That Engels wished to abolish the market entirely and replace its allocative function by a fully-fledged Central Plan relating to production and distribution is suggested already in Principles of Communism, Question 14 which explains the general conception of the "new social order." The key feature is central planning "for the social good" (referred to as "association"), "community of property" and income distribution "by common agreement":

Above all, it will have to take the running of industry and all branches of production in general out of the hands of separate individuals competing with each other and instead will have to ensure that all these branches of production are run by society as a whole, i.e., for the social good, according to a social plan and with the participation of all members of society. It will therefore do away with competition 
and replace it by association. Since the running of industry by individuals had private ownership as its necessary consequence and since competition is nothing but the manner in which industry is run by individual private owners, private ownership cannot be separated from the individual running of industry and competition. Hence, private ownership will also have to be abolished, and in its stead there will be common use of all the instruments of production and the distribution of all products by common agreement, or the so-called community of property. The abolition of private ownership is indeed the most succinct and characteristic summary of the transformation of the entire social system necessarily following from the development of industry, and it is therefore rightly put forward by the Communists as their main demand (MECW 6:348).

And at the close of his twelve proposals for the Communist system listed under Question 18, there is mention of the abolition of money: "when all capital, all production, and all exchange are concentrated in the hands of the nation, private ownership will have ceased to exist, money will have become superfluous, and production will have so increased and men will have so much changed that the last forms of the old social relations will also be able to fall away" (p. 351).

10. Marx's labour-certificates would not circulate, i.e., would not constitute money. They would be used solely to redeem consumer goods from the relevant producing authority, a cloakroom function only. On this matter see also Capital Vol. II: "The producers may, for all it matters, receive paper vouchers entitling them to withdraw from the social supplies of consumer goods a quantity corresponding to their labour time. These vouchers are not money. They do not circulate" (MECW 36:356). On objections to Rodbertus and Dühring in this regard (see, pp. 19-20).

11. Marx adds: "Besides, one worker is married, another not; one has more children than another, etc., etc. Thus, given an equal amount of work done, and hence an equal share in the social consumption fund, one will in fact receive more than another, one will be richer than another, etc. To avoid all these defects, right would have to be unequal rather than equal."

12. Again one notes the absence of markets and exchange, thus of money and "value" - the indirect measure of labour embodied - in Marx's perception of the first phase of Communist society (see also, p. 20). This theme is much developed in the Grundrisse, MECW 28:92-96.

13. Marx also raises the objection to the Party programme that equal distribution " $\mathrm{t}] \mathrm{o}$ all members of society" begs the question: "To those who do not work as well? What remains then of the 'undiminished proceeds of labour'? Only to those members of society who work? What remains then of 'the equal right' of all members of society?" (p. 84).

14. Marx read and approved of Anti-Dühring and in fact collaborated with Engels in various ways (see editorial preface, MECW 25:xiii).

15. The term "value" is inappropriate (see, p. 20).

16. Engels maintained that Dühring himself, by introducing an entire range of character differences, undermined his own general notion of equality, as had already been done by Rousseau in Discours sur l'origine et les fondemens de l' inégalité (1754; published 1755) (pp. 90-91).

17. Sowell in his account sees no problem and writes simply: "Although it may be empirically true that different ideologies generally regard central planning in different ways, it is not ultimately in principle an ideological question. Marx and Engels were unsparing in their criticisms of their fellow socialists and fellow communists who wanted to replace price competitin with central planning" (1980:218). But we see a problem to be solved, that Marx and Engels appreciated the competitive pricing mechanism but nonetheless supported central control.

18. This opens up a range of issues relating to foreign trade.

19. This is true also of ancient Indian communities and the family communities of the southern Slavs, whose "members are directly associated for production; the work is distributed according to tradition and requirements, and likewise the products to the extent that they are destined for consumption."

20. The opening reference to variations in the "specifically useful character" of labour indicates the first not the mature stage of communism.

21. Here Engels refers to a passage in his earlier Outlines of 1844 cited below.

22. He adds: "The scientific justification for this statement. . . was made possible only by Marx's Capital."

23. There is, however, a passage that might be read as allowing consumer freedom: 
The truth of the relation of competition is the relation of consumption to productivity. In a world worthy of mankind there will be no other competition than this. The community will have to calculate what it can produce with the means at its disposal; and in accordance with the relationship of this productive power to the mass of consumers it will determine how far it has to raise or lower production, how far it has to give way to, or curtail, luxury. But so that they may be able to pass a correct judgment on this relationship and on the increase in productive power to be expected from a rational state of affairs within the community, I invite my readers to consult the writings of the English Socialists, and partly also those of Fourier (p. 435).

24. In corrections in Marx's hand, "to an article" ("à un objet”) is replaced by "aux différents objets" and the qualifying "social" is inserted (editorial notes, 134n).

25. The question of freedom of consumer choice was central to the Dobb-Lerner debate of the 1930s: Dobb (1933); Lerner (1934-1935); Dobb (1934-1935); Lerner (1934-1935).

26. Marx at this period emphasised the time constraint under all social arrangement (1845; MECW 4:49-50); but Engels' more general perspective was acceptable to him (see Hollander 2000). We may, therefore, dispose of a standard objection as by Wicksell:

Even in a socialist state, rent and interest would play exactly the same role as they do now, in determining the reciprocal value of the products, the only difference being that land and capital would then have other owners. It is simply Utopian to imagine that any transformation in the conditions of ownership would give natural forces existing in limited quantities the character of free commodities... (cited Gårdland 1958:119-120).

The second of Engels' formulations continues by extending the observation to labour. Under competition "the product of labour as wages is separated from it, and is in its turn as usual determined by competitionthere being, as we have seen [...], no firm standard determining labour's share in production." But under communal arrangement "this unnatural separation also disappears. Labour becomes its own reward, and the true significance of the wages of labour, hitherto alienated comes to light—namely the significance of labour for the determination of the production costs of a thing." The problem I find here is that there is a firm standard under capitalism, namely subsistence costs.

27. In a later letter to August Bebel, Engels writes more generally of cooperative organization as only "transitionally" acceptable and subject to the same qualification regarding national control:

Nor have Marx and I ever doubted that, in the course of transition to a wholly communist economy, widespread use would have to be made of cooperative management as an intermediate stage. Only it will mean so organising things that society, i.e. initially the State, retains ownership of the means of production and thus prevents the particular interests of the cooperatives from taking precedence on those of society as a whole (20-23 January 1886; MECW 47:389).

Since national control is insisted upon the question of the role of cooperatives is far less significant than in the case of J.S Mill; even cooperatives could be incorporated within the "social regulation of production upon a definite plan" (see, p. 22). This too seems to have been Marx's position (see, p. 11).

28. Other commentators have also hit upon "parallels" between Marx and Hayek though, to my knowledge, not with respect to our specific topic. Thus, Lord Desai refers to a common concern "with modelling capitalism, its cyclical character, the importance of money and credit, its long-term profits.... Their analysis of the dynamics of capitalism is similar....There is also much in common in capital theory...." (1997). Also Howard and King: "Peculiar as it may seem, Friedrich von Hayek and James Buchanan have both broken with much of traditional neoclassical theory, and in doing so have unwittingly reasserted basic themes of Marx's economics by recognising that capitalist systems are indeed 'organic unities"' (2001:795). For various "parallels" relating to business cycle theory in particular, see references in Ebenstein (2001:378379).

29. The parallel would presumably be rejected by those who believe that Marx applied post-capitalist standards of morality as embedded in the experience and consciousness of the proletarian class of non-property owners (see above, note 2). 
We do well to recall here our caution regarding the very different intentions of the parties. Baldly stated, Marx and Engels refused to analyse capitalism in ethical terms because they wished to see that system replaced, and sought to focus attention on the main issue for them, that of "exploitation," an issue pertinent to the realm of production rather than exchange including income distribution; hence their objection to the Proudhonian anarchists, Dühring, other social democratic reformers and the earlier "Ricardian socialists" who threatened to divert attention to marginal concerns. Hayek's refusal stemmed from his wish to see the system conserved, fearing that an approach in terms of ethics would divert attention from his main issue — that social order results from human action rather than design.

30. The view has been attributed to Hayek that to redistribute wealth from those who succeed to those who fail would not only be "unjust" but would threaten wealth-creation, since there are "unified laws of production and distribution... one cannot modify distribution without disturbing production" (Tomass, 1998:288). This attribution is stated rather too strongly as we shall presently see (p. 28). David Levy has suggested to me that a necessarily deleterious effect on growth stemming from redistribution in labour's favour characterise rather the positions of Feldstein and Lucas than that of Hayek.

31. I surmise that their apparent rejection of free consumer choice under Communism can also be attributed to such a concern.

32. For the same general argument, see also Mises (1947), ch. 2 in particular: "The Dictatorial, Anti-democratic and Socialist Character of Intervention", 23-34. An elaboration will be found in Mises 1963. Notwithstanding, at the close of his 1950 address, Mises insists that "the coming of socialism is not inevitable" and warns rather of the "defeatism" spread by many "self-styled non-Marxians"- the "middle-of-the-roaders who think they have been successful when they have delayed for some time an especially ruinous measure" (pp. 33-34). Accordingly:

What can prevent the coming of totalitarian socialism is only a thorough change in ideologies. What we need is neither anti-socialism nor anti-communism but an open positive endorsement of that system to which we owe all the wealth that distinguishes our age from the comparatively straightened conditions of ages gone by (p. 35).

See also Hayek, 1967[1944]:xivf, on the psychological alteration to the character of a people due to long-term extensive government control.

33. The closing phrase implies that for Mises the socialist position recognized consumer sovereignty; but this is less clear in what follows.

34. See also:

Interventionism cannot be considered as an economic system destined to stay. It is a method for the transformation of capitalism into socialism by a series of successive steps. It is as such different from the endeavors of the communists to bring about socialism at one stroke. The difference does not refer to the ultimate end of the political movement; it refers mainly to the tactics to be resorted to for the attainment of an end that both groups are aiming at (p. 128).

35. Unlike Hayek who warned of the prospective transition to communism by societies with extensive programs of nationalization (1944:60-61), Mises rather played down the British nationalization program: "Great Britain is to be called a socialist country not because certain enterprises have been formerly expropriated and nationalized, but because all the economic activities of all citizens are subject to full control of the government and its agencies" (p. 26).

36. It has been pointed out to me that even Mises saw a role for government in policing and the courts.

37. Hayek did not deny the suffering by some from the operation of the market system, and himself insisted that "in competition chance and good luck are often as important as skill and foresight in determining the fate of different people"; he allowed too that chances are unequal considering the restricted opportunities open to the poor, exacerbated by inheritance (1944:101-102). His case was based rather on the greater freedom even of the badly-paid unskilled worker under a market than under a control system and this even should material comforts be lower. For the outcome "depends at least partly on the ability and enterprise of the people concerned," and is above all subject to "the impersonal character of the process by which everybody has to take his chance and no person's view about what is right and desirable overrules that of others" (p. 102). Nonetheless, provided the 
latter conditions are not compromised - and though we tend "to habitually overestimate the extent to which inequality of incomes is mainly caused by income derived from property"-Hayek conceded "a strong case for reducing...inequality of opportunity as far as congenital differences permit...." Beyond this, he also made out a strong case for a guaranteed safety net: "in a society that has reached the general level of wealth which ours has attained there is no doubt that some minimum of food, shelter, and clothing, sufficient to preserve health and capacity to work, can be assured to everybody" (p. 120). And he recognized a legitimate role for the state with respect first to social insurance: "there is no reason why the state should not assist the individuals in providing for those common hazards of life against which, because of their uncertainty, few individuals can make adequate provision" (p. 121); and secondly to macroeconomic stability: "though its solution will require much planning in the good sense, it does not-or at least need not-require that special kind of planning which according to its advocates is to replace the market... [T] he very necessary efforts to secure protection against these fluctuations do not lead to the kind of planning which constitutes such a threat to our freedom" (pp. 121-122).

38. See also Engels, Socialism: Utopian and Scientific (1880), MECW 24:318.

39. For all that an allowance was made for the achievement of proletarian power via the ballot box at least in the British case; see for example the Principles of Communism (MECW 6:350). On the role allowed coercion during the transition period to Communism, see Popper 1945:328n6; Duncan 1973:180-181.

40. Much later, in discussing expropriation of big landed proprietors once "our Party is in possession of political power", Engels recalled that "[w]e by no means consider compensation as impermissible in any event; Marx told me (and how many times!) that in his opinion we would get off cheapest if we could buy out the whole lot of them" (Engels 1958[1894]:II, 438).

41. There is a contrast between Engels and Marx on the matter of inheritance. Marx in the Manifesto goes so far as to call for the "abolition of all right to inheritance" (MECW 6:505). Engels in the Principles of Communism did not (then at least) go so far, recommending a "high inheritance tax, abolition of inheritance by collateral lines (brothers, nephews, etc.), and "[e]qual rights of inheritance to be enjoyed by illegitimate and legitimate children" (responses to Questions 1, 11; MECW 6:350-351).

42. On the role of Western advisors in the Russian economic disaster of the 1990s, see Klein and Pomer (2001).

43. The general context reflects Mises' view of "interventionism" (see, note 34).

44. Lenin is represented by Mises as following the radical path involving the expropriation of "all farms, plants and shops" to be operated "by a bureaucratic apparatus as departments of the government. The whole of society, says Lenin, becomes "one office and one factory, with equal work and equal pay" [State and Revolution 1932:84]..." (Mises:30).

45. Mises may well have had in mind the following famous passage regarding the historical process:

Along with the constantly diminishing number of the magnates of capital, who usurp and monopolise all advantages of this process of transformation, grows the mass of misery, oppression, slavery, degradation, exploitation; but with this too grows the revolt of the working class, a class always increasing in numbers, and disciplined, united, organised production itself. The monopoly of capital becomes a fetter upon the mode of production, which has sprung up and flourished along with, and under it. Centralisation of the means of production and socialisation of labour at last reach a point where they become incompatible with their capitalist integument. This integument is burst asunder. The knell of capitalist private property sounds. The expropriators are expropriated (Capital I; MECW 35:750).

46. Similarly, as we have seen, Engels explains in his Principles of Communism why the abolition of the private property system could not have been achieved at an earlier period, invoking the huge growth of productive potential already achieved under capitalism which was essential for the successful implementation of the subsequent stage, and yet he proceeds to elaborate on the retention of a capitalist sector under communism to assure the further requisite expansion of productive capacity.

\section{References}

Baumol, W. J. (2001) "Priceless Value: Misunderstood Concerns (or almost so) of Marx and Ricardo." In: Forget, E. and Peart, S. (Eds.) Reflecting on the Classical Canon in Economics, pp. 224-240. London: Routledge. 
Caldwell, B. J. (1997) "Introduction" to Hayek, F. von, 1997, pp. 1-50.

Desai, Lord (1997) In: Frowen, S. F. (Ed.) Hayek: Economist and Social Philosopher. A Critical Retrospect, pp. 1-8. London: Macmillan.

Dobb, M. (1933) "Economic Theory and the Problems of a Socialist Economy." Economic Journal, 43: 588-598. Dobb, M. (1934-1935) "Economic Theory and Socialist Economy: A Reply." Review of Economic Studies, 2: $144-151$.

Duncan, G. (1973) Marx and Mill: Two Views of Social Conflict and Social Harmony. Cambridge: Cambridge University Press.

Ebenstein, A. (2001) Friedrich Hayek: A Biography. London: Palgrave.

Engels, F. (1958 [1894]) "The Peasant Question in France and Germany." In: Karl Marx and Frederick Engels: Selected Works, II, pp. 420-440. Moscow: Foreign Languages Publishing House.

Gårdland, Torsten (1958) The Life of Knut Wicksell. Stockholm: Almquist and Wicksell.

Hayek, F. von (1967 [1944]) The Road to Serfdom. Chicago: University of Chicago Press.

Hayek, F. von (1997 [1939]) "Prices vs. Rationing." In: Frowen, S. F. (Ed.) Hayek: Economist and Philosopher: A Critical Retrospect, pp. London: MacMillan; New York: St. Martin's Press.

Hayek, F. von (1960) The Constitution of Liberty. Chicago: University of Chicago Press.

Hollander, S. (2000) "The Marx-Engels Relation: On the Significance of Engels" Outlines of Political Economy, the Umrisse" (unpublished ms.).

Hollander, S. (1985) The Economics of John Stuart Mill. Toronto: University of Toronto Press.

Howard, M. C. and King, J. E. (2001) "Where Marx was Right: Towards a More Secure Foundation for Heterodox

Economics." Cambridge Journal of Economics 25: 785-807.

Husami, Z. (1978) "Marx on Distributive Justice." Philosophy and Public Affairs, 8: $27-64$.

Hutchison, T. W. (1981) The Politics and Philosophy of Economics: Marxians, Keynesians and Austrians. Oxford: Blackwell.

Klein, L. and Pomer, M. eds. (2001) The New Russia: Transition Gone Astray. Cambridge: Cambridge University Press.

Lerner, A. (1934-1935) "Economic Theory and Socialist Economy." Review of Economic Studies, 2: 51-61.

Lerner, A. (1934-1935) “A Rejoinder to Dobb.” Review of Economic Studies, 2: 152-154.

Mises, L. von (1947) Planned Chaos. Irvington-on-Hudson. NY: Foundation for Economic Education.

Mises, L. von (1980 [1950]) Planning for Freedom. South Holland, IL: Libertarian Press.

Mises, L. von (1963) Human Action: A Treatise on Economics. 3rd revised edn., New Haven: Yale University Press.

Popper, K. R. (1983 [1945]) “Marx’s Theory of the State.” In: Miller, D. (Ed.) A Pocket Popper, pp. 326-337. Fontana: Oxford.

Service, R. (2000) Lenin: A Biography. London: McMillan.

Sowell, T. (1980) Knowledge and Decision. Princeton: Princeton University Press.

Tomass, M. (1998) “On the Relativist Fallacy.” Journal of the History of Economic Thought, 20: 279-298.

Tucker, R. (1969) The Marxian Revolutionary Idea. New York: Norton.

Vaughn, Karen (1998) "Review (Caldwell 1997)." Journal of the History of Economic Thought, 20:235-237.

Wood, A. (1972) "The Marxian Critique of Justice." Philosophy and Public Affairs, 1: 244-282. 